Open Access

\title{
An interactive and augmented learning concept for orientation week in higher education
}

Nguyen Nguyen, Tuomo Muilu, Amir Dirin ${ }^{*}$ and Ari Alamäki

\author{
* Correspondence: amir.dirin@ \\ yahoo.com \\ Business Information Technology \\ Department, Haaga-Helia UAS, \\ Helsinki, Finland
}

\begin{abstract}
This paper details the concept development process for an interactive and augmented reality based application that compensates for attending Orientation Week at a higher education institution. The application will help freshmen learn about the institution's environment and campus, degree program, and course curriculum before school starts. For efficiency and to elicit high emotional engagement, various pedagogical and technological approaches are used for presenting the content, such as gamification and augmented reality. Awareness of their future learning environment, study path, and course details helps students reduce their fear of failure, and this, in turn, prevents educational withdrawal. In addition to raising awareness, the interactive augmented learning for orientation application saves educational institutions significant time and resources by preparing new students for their educational journey on their personal mobile devices. The contribution of this paper is both for academicians and practitioners regarding the process for developing an innovative concept.
\end{abstract}

Keywords: Concept design, User-centered design, Emotional design, Augmented reality, Orientation week

\section{Introduction}

The smartphone's penetration among the youth is increasing at a fast pace (Boulos, Wheeler, Tavares, \& Jones, 2011; Dirin et al., 2013a). Today, youth spend more time using smartphone applications than personal computers. The penetration and excessive usage are the result of advancements in wireless technologies and smartphone capabilities. Indeed, mobile applications, such as games, social networking, entertainment, personal, and professional applicationsare proliferating rapidly. These applications are constantly competing for users' time and attention (Dirin et al., 2013a). Therefore, an engaging mobile learning (m-learning) application requires a carefully design that provides emotional connection to its users. Furthermore, m-learning applications, such as a mobile augmented reality (MAR) application, must meet students' essential educational requirements and encourage them to engage with the application on their smartphones (Seong, 2006). User-centered design (UCD) for m-learning applications (Dirin \& Nieminen, 2015) has proven to be a successful framework. As the

(C) The Author(s). 2018 Open Access This article is distributed under the terms of the Creative Commons Attribution 4.0 International License (http://creativecommons.org/licenses/by/4.0/), which permits unrestricted use, distribution, and reproduction in any medium, provided you give appropriate credit to the original author(s) and the source, provide a link to the Creative Commons license, and indicate if changes were made. 
name suggests, this framework puts the targeted application's intended users at the center of its design and development.

The main goal of this study was to design and develop an application concept containing many different features to support new students before they start school. Additionally, the solution would need to engage students emotionally by applying design aspects of various technologies, such as augmented reality (AR) and virtual reality (VR), to ease the learning process and students' adaptation to the educational environment.

The solution provided by the research team is a mobile orientation application for freshmen at universities and polytechnics. As a proof-of-concept prototype, the team selected the Business Information Technology (BITe) degree program at Haaga-Helia University of Applied Science (UAS) as a case study. The solution provides a way for new students to gain all the relevant information that a weeklong orientation contains at their own pace, from their mobile phone. This solves the problem of missing days of orientation due to illness or late flights, and it reduces the number of person-hours needed by the school to organize the orientation.

The study began with a feasibility analysis, in which the concept idea was evaluated according to several different aspects. Next, the research team investigated the real user experience of the application to determine the user requirements. Then the available information about the concept design was studied. Subsequently, the idea was implemented in different phases of prototypes, after which the application prototype was tested by chosen participants for usability evaluation. Finally, the team analyzed the evaluation results to improve the concept further.

\section{Background}

It is conventional for higher education institutions to organize an Orientation Week for new students. The aim is to help students adapt to their new environment and educational setup. This orientation plays an important role in enabling students to learn about the environment, courses, and campus that they will be part of for the next few years. Therefore, special attention is required to provide efficient and effective orientation contents.

Orientation Week has a significant impact on students psychologically, sociologically, and in terms of future learning efficiency. Murphy et al. (2002) present a web-based college orientation. Orientation Week is also important for new employees in companies; Acevedo and Yancey (2011) present their design of a framework for a Realistic Orientation Program for New Employee Stress (ROPES). In the educational context, Fitz-Walter, Tjondronegoro, \& Wyeth (2011) propose gamification to help new students at a university. They apply game concepts to their Oriented Passport to provide orientation to new students (Fitz-Walter, Wyeth, Tjondronegoro, \& Johnson, 2014) and study the effects of achievement on students attending their university's Orientation Week.

In addition to the principles of UCD, it is important to understand how learning technologies affect students' learning. Past research has shown that facilitating the activity of learners improves learning results and professional skills (Glaserfeld, 1995). Additionally, studies have shown that students' learning is situational (Anderson, Reder, \& Simon, 1996), and they learn better when they have an actual need to acquire new 
knowledge and solve problems. Therefore, when designing m-learning solutions, designers should focus on what is going on in the students' minds while they try to solve problems concerning their studies. Suomala, Alajääski, and Alamäki (1999) show in their empirical study that teaching methods and practices have an impact on the development of students' cognitive skills. This sets pedagogical requirements for the concept development. Anderson et al. (1996) state that students learn best when abstract instruction and concrete illustration are combined. Additionally, videos and VR, and VR applications are solutions that potentially improve concrete illustration.

While educating new students about university studies-which is the educational goal of this concept development project-there should be a particular focus on higher levels of thinking skills by combining abstract-level thinking with the students' concrete learning and education practices. It is also important that the orientation application enables students to connect what they have learned to their current everyday experiences and understanding. According to von Glaserfeld (1995), there are things that can be learned mechanically or that only require mechanical learning. This means that memorization and recall are not worthless. Hence, in promoting students' learning, the concept of interactive augmented learning for orientation (IALO) should both support the delivery of useful information and activate students to contextualize knowledge to their own experiences and needs. This aligns with research on higher education that highlights the importance of student engagement (Vuori, 2014). Alamäki and Mäkinen (2005) emphasize that digital learning should be seen as a strategic approach to improving the success of organizations, rather than an operational tool. Thus, designing and creating m-learning solutions in higher education and integrating them into the conventional learning methods promotes the renewal of educational processes. Blended learning, where digital learning methods are seamlessly integrated into conventional classroom learning, creates more effective, meaningful learning experiences for students (Garrison \& Kanuka, 2004; Lopez-Perez, Perez-Lopez, \& Rodriguez-Ariza, 2011).

\section{Research questions and design methodology}

The aim of this study to come up with an application concept that helps freshmen to learn about their educational institutes. Hence, this study pursues to answer the following question:

What kind of mobile application may assist freshmen to adjust their new educational environment?

To answer the above question this study applied the UCD principle (Abras, Maloney-Krichmar, \& Preece, 2004) and mLUX m-learning application framework (Dirin \& Nieminen, 2015). The mLUX framework consists of three layers: (1) the role-players, (2) the process, and (3) the context of use. The mLux framework process is shown in Fig. 1.

The mLux framework (Fig. 1) starts with the User Study Phase to understand the users. Following the studying of users is the Data Analysis Phase. In this phase, users' data is collected and analyzed to organize the importance of user requirements. The next phase is Idea Creation, in which a scenario and paper prototype are made according to the user requirements. In this phase, the user-case scenario and the paper prototype are tested. The final phase is the Product Concept that involves the making of a 


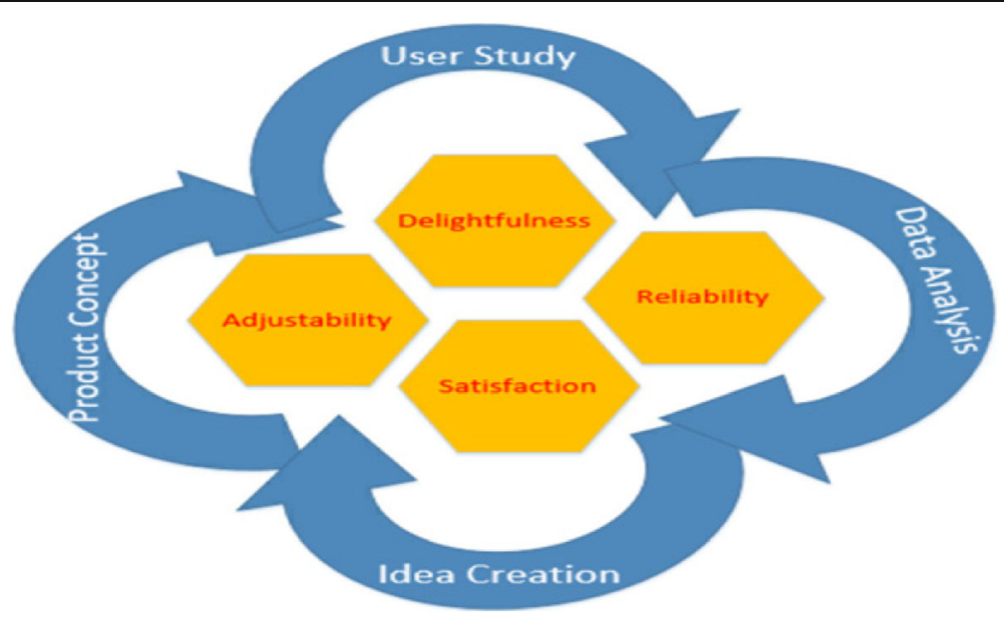

Fig. 1 mLUX framework for m-learning application design and development (Dirin \& Nieminen, 2015)

lo-fi prototype of the concept. In this phase, the prototype is tested with real users to gather feedback on the feasibility of the concept and the usability of the prototype.

\section{User study phase (understanding the user)}

The user study phase is the essence of UCD for m-learning application development. During this phase, target stakeholders are identified, and their real needs are investigated by applying various user study methods, such as a diary and interviews. The diary, for example, helps the designers learn about the user and the environment in which they often interact. Standard UCD methodology recommends the involvement of 3-10 target users at various stages of the user study (Usability Research Group, 2002).

\section{Data analysis phase (identifying the interactions)}

The data gathered during the previous phase are row data, which require processing for identifying the users' real needs. Various data analysis methods, such as transcript coding (Gorden, 1998), user task and environment analysis (Hackos \& Redish, 1998), can help in classifying and categorizing the user requirements. Affinity diagrams (Holtzblatt, Wendell, \& Wood, 2005) are the recommended method for categorizing and prioritizing the requirements.

\section{Idea creation phase (producing the design solution)}

During this phase, it is necessary to confirm those categorized and prioritized requirements with potential test users. This confirmation ensures that the designers understand the users' needs properly. Moreover, this offers another opportunity for the target users to add to the proposed requirements. The categorized requirements can be presented as scenarios. Scenario design (Rosson \& Carroll, 2002) is the best approach for the m-learning application concept design method, as the scenario speaks the user's language and often avoids technical terms and complexities. 


\section{Product concept (evaluating the design)}

During this phase, the application concept is modified according to the data gathered during the previous phase. The application concept is then ready to be implemented as a non-functional prototype. The prototype consists of the potential user interface components and the navigations of various screens. During the last stage of users' involvement in the design process, a usability evaluation test is conducted for the proposed application prototype. Subsequently, the application design is refined in accordance with the usability test results and delivered as a potential and final application concept.

\section{Application concept design}

\section{User study and data collection}

Various user study methods were deployed to gather information on how students carried out the tasks, such as questionnaires and semi-structured interviews. The initial user study process started with collecting the overall user profile from Haaga-Helia students, as the designated users of the m-learning environment. A short interview session was conducted through phone calls and face-to-face interviews with four students beginning BITe in 2016. The answers were recorded using a mobile phone and were later transcribed and analyzed. The user profile is described in Table 1.

The learning environment was designed for freshman students, and the user profile was that of a Haaga-Helia freshman student. The freshman students' persona at Haaga-Helia are smartphone users and are advanced at using the phone's browser (Table 1). Moreover, they can use basic office software, such as Microsoft Office and Outlook, as well as cloud services, such as Google Drive and OneDrive. Three of the four interviewees were under 30 years old. They were fast learners, who were familiar with common information and communication technologies. However, orientation for the Haaga-Helia learning management system put a damper on the first week of the semester for freshmen. Three interviewees said that they had had problems with accessing or finding the right information for the right tasks during the first few weeks of the first semester. They spent time learning how to use facilities, which could easily be shown in a tutorial before they arrived at the school.

Table 1 User profile based on BITe 2016 students

\begin{tabular}{|c|c|c|c|c|c|c|}
\hline User & Gender & Age & $\begin{array}{l}\text { Experienced } \\
\text { smartphone }\end{array}$ & $\begin{array}{l}\text { Software used } \\
\text { for school }\end{array}$ & $\begin{array}{l}\text { Attend all } \\
\text { orientation days }\end{array}$ & $\begin{array}{l}\text { Difficulties/problems } \\
\text { during orientation week }\end{array}$ \\
\hline 1 & $\mathrm{~F}$ & 30 & Y, iPhone & $\begin{array}{l}\text { Google Drive, } \\
\text { Outlook }\end{array}$ & Y & $\mathrm{N}$ \\
\hline 2 & F & 19 & Y, Android & $\begin{array}{l}\text { One Drive, MS } \\
\text { Office, Outlook }\end{array}$ & Y & $\begin{array}{l}\text { Y: printing process, } \\
\text { logging in to VDI }\end{array}$ \\
\hline 3 & M & 22 & Y, iPhone & $\begin{array}{l}\text { MS Office, One } \\
\text { Drive }\end{array}$ & N (3/7 days) & $\begin{array}{l}\text { Y: finding timetable and } \\
\text { course description }\end{array}$ \\
\hline 4 & M & 21 & $Y$, Android & $\begin{array}{l}\text { Outlook, } \\
\text { OneDrive }\end{array}$ & Y & $\begin{array}{l}\text { Y: accessing/downloading } \\
\text { the school software (MS } \\
\text { Office, etc.) }\end{array}$ \\
\hline
\end{tabular}




\section{Data analysis}

The team selected four Haaga-Helia's sophomore students with whom to conduct interviews about their activities during their first 2 weeks as freshmen in the BITe degree program.. We considered interview as an appropriate method to collect information from users. The advantages of an interview, whether a face-to-face or as a telephone interview, enable to collectin-depth knowledge and interpersonal dynamics (MacDonald \& Headlam, 2009). The aim of these interviews was to uncover problems the students had encountered during Orientation Week as they recalled the information about the school environment, tools, and learning system. Moreover, the in-depth interview helped us to define the users' profile (Table 1) and identify the users' expectations and requirements regarding the Orientation Week of Haaga-Helia's BITe program. The interview transcripts were analyzed to identify the frequencies of the repeated terms and actions among the interviewees. The interview transcript is summarized in the user-task matrix in Table 2.

The interview transcript analysis (Coding, 2012) showed that the interviewees had participated in $72 \%$ of the common activities during Orientation Week, despite the fact that all activities were mandatory. The students reasoned that the mandatory attendance policy creates disadvantages for students who cannot attend one of the orientation days and consequently miss that day's valuable knowledge. Moreover, there were no alternative ways for students who had missed part of the orientation to regain this experience and knowledge. Owing to this problem, some students had trouble managing the Haaga-Helia educational tools later on, which created frustration and wasted valuable studying time. To devise solutions and enhance services in the m-learning environment for the students, the research team analyzed the interview data using the framework of an affinity diagram (Holtzblatt et al., 2005). The team used this method to extract the information from the interviewees into an overall picture of user requirements as an affinity diagram. The diagram was created to synthesize the interview data to find the key words and actions that were mentioned repeatedly throughout the conversation. After picking out these key terms, the team grouped similar properties together into logical groups of users' tasks Furthermore, the categorization of the tasks was based on environment which the tasks occurs, therefore we applied tasks and environment analysis (Hackos \& Redish, 1998).. The diagram breaks down users' main tasks and the purposes of their activities. Using the diagram helped the research team understand which features of the m-learning environment to prioritize. It was essential for the features of the application to solve users' problems and support their learning-related activities and usage purposes. The affinity diagram is presented in Table 3.

Table 2 User-task matrix during Orientation Week

\begin{tabular}{|c|c|c|c|c|}
\hline & User 1 & User 2 & User 3 & User 4 \\
\hline Checking course information by navigating through MyNet & $x$ & $x$ & $x$ & $x$ \\
\hline Learning how to use Asio, Winhawille, and Moodle altogether & $x$ & $x$ & & \\
\hline Learning how to use the facilities and equipment on the Pasila campus & $X$ & $x$ & & \\
\hline Communicating with classmates and teachers & $x$ & & $x$ & X \\
\hline Learning how to use VDI & $x$ & $x$ & & \\
\hline Learning about benefits, such as discounts, software packages, and services & $x$ & & $x$ & $x$ \\
\hline Making and checking one's own timetable & X & X & $x$ & $x$ \\
\hline
\end{tabular}


Table 3 List of tasks recognized during the data analysis

\begin{tabular}{|c|c|c|c|c|c|}
\hline Task group & $\begin{array}{l}\text { Checking } \\
\text { information }\end{array}$ & $\begin{array}{l}\text { Learning the } \\
\text { school's system }\end{array}$ & Socializing & $\begin{array}{l}\text { Receiving } \\
\text { student } \\
\text { benefits }\end{array}$ & $\begin{array}{l}\text { Makin own } \\
\text { timetable }\end{array}$ \\
\hline Subtasks & $\begin{array}{l}\text { Checking study } \\
\text { info on MyNet }\end{array}$ & $\begin{array}{ll}\text { Using } & \text { Asio, } \\
\text { Winhawille, } \\
\text { Moodle, VDI, } \\
\begin{array}{l}\text { and } \\
\text { campus's } \\
\text { facilities }\end{array}\end{array}$ & $\begin{array}{l}\text { Meeting and } \\
\text { communicating with } \\
\text { other students and } \\
\text { teachers }\end{array}$ & $\begin{array}{l}\text { Receiving } \\
\text { student } \\
\text { benefits }\end{array}$ & $\begin{array}{l}\text { Choosing courses } \\
\text { and creating one's } \\
\text { own timetable for } \\
\text { the semester }\end{array}$ \\
\hline $\begin{array}{l}\text { User } \\
\text { expectations }\end{array}$ & $\begin{array}{l}\text { To know the } \\
\text { most important } \\
\text { information } \\
\text { about potential } \\
\text { courses }\end{array}$ & $\begin{array}{l}\text { To study more } \\
\text { efficiently, plan } \\
\text { studies } \\
\text { personally, and } \\
\text { keep track of } \\
\text { study progress }\end{array}$ & $\begin{array}{l}\text { To create good } \\
\text { relationships and } \\
\text { teamwork and get } \\
\text { support }\end{array}$ & $\begin{array}{l}\text { To support } \\
\text { student life at } \\
\text { school and } \\
\text { society }\end{array}$ & $\begin{array}{l}\text { To create a } \\
\text { personal study plan } \\
\text { with suitable } \\
\text { courses and make } \\
\text { one's own } \\
\text { timetable }\end{array}$ \\
\hline $\begin{array}{l}\text { Team task } \\
\text { aspects }\end{array}$ & $\begin{array}{l}\text { Can share course } \\
\text { information and } \\
\text { rate/write } \\
\text { reviews }\end{array}$ & $\begin{array}{l}\text { Can learn } \\
\text { together }\end{array}$ & $\begin{array}{l}\text { Can book meeting } \\
\text { rooms }\end{array}$ & $\begin{array}{l}\text { Can invite and } \\
\text { share with } \\
\text { other students } \\
\text { to obtain } \\
\text { benefits } \\
\text { together }\end{array}$ & $\begin{array}{l}\text { Can see how many } \\
\text { friends or } \\
\text { classmates choose } \\
\text { the same courses }\end{array}$ \\
\hline $\begin{array}{l}\text { End-user } \\
\text { validation }\end{array}$ & $\begin{array}{l}\text { Users } \\
\text { successfully } \\
\text { check all } \\
\text { information } \\
\text { needed without } \\
\text { problems }\end{array}$ & $\begin{array}{l}\text { User can obtain } \\
\text { knowledge and } \\
\text { understand how } \\
\text { to use it } \\
\text { practically }\end{array}$ & $\begin{array}{l}\text { User can develop } \\
\text { social and soft skills } \\
\text { and connect with } \\
\text { others with the same } \\
\text { goals }\end{array}$ & $\begin{array}{l}\text { User can earn } \\
\text { rewards from } \\
\text { study and } \\
\text { works, and use } \\
\text { them to } \\
\text { facilitate life }\end{array}$ & $\begin{array}{l}\text { User can create a } \\
\text { suitable timetable } \\
\text { for their interests } \\
\text { and preferences or } \\
\text { be in the study } \\
\text { groups that they } \\
\text { prefer }\end{array}$ \\
\hline
\end{tabular}

The affinity diagram of the data analysis creates the users' flow which they recalled the order of their tasks during the interviews (Fig. 3). The user starts the journey with a challenge or task, which is coded in red. The goal coded in green is for the user to win the challenge and meet their expectations, coded in yellow. In addition, the aspect of teamwork in a challenge, coded in blue, suggests activities that users can do together. The diagram provides a clear picture of what users need to complete their tasks and what they want to have gained at the end of each task.

\section{Concept development}

Employing the requirements list provided in the user study, a scenario was created and shared with users.

An excerpt of the scenario is seen in Fig. 2.

The full scenario that includes the excerpt (Fig. 2) was given to three participants. After the reading, they were asked the following questions: "What do you think about the scenario? Is it easy to understand? Can you see yourself using the same app that Eric uses? Do you have any suggestions of app functions to add or omit from the scenario?"

All three users gave positive feedback regarding their level of understanding of the application's use and potential. Based on this feedback, a shortened summary of the

Eric is a new student, who received his acceptance letter to Haaga-Helia in June. He is a freshman student in the BITe program. With the letter of acceptance, Eric also received a barcode or link labeled "HH Orientation Game." Eric accesses the link and loads the game on his mobile phone. He can then start to learn about Haaga-Helia and BITe while playing the game. Within a few days, Eric has gained visualized knowledge of his campus, his Haaga-Helia profile and teachers, as well as practical information about using campus and online services...

Fig. 2 Sample of application concept as a scenario 
scenario was created and used in the Google forms survey given to future participants online. The evaluation of the scenario content was necessary because it would be used in usability testing later, and thus needed to be clear and easy to understand. Figure 3 presents screenshots of the IALO application.

The researchers applied the theories of Gestalt (Todorovic, 2008) and Galitz (2007) and their principles in the prototype user interface (UI) design approach. The designed icons in the concept have universal meaning for the functions that they represent (Fig. 3). When they recognize similar icons used in other popular applications, users can apply their existing knowledge to grasp the features.

\section{Repetition, consistency, and simplicity}

Consistency was maintained in the UI throughout the concept design; in addition, the same color palette was used for similar elements, allowing users to associate colors with information (Fig. 3). This methodical design was applied for each functional button and information section. The purpose was to give users a sense of unity and support their decision-making process.

\section{Alignment, balance, hierarchy, and proximity}

The alignment of all speech boxes followed a pattern, where there was always a small gap on the sides. Moreover, relevant speech boxes were grouped together, leaving an equal distance between all boxes, thereby creating eye-movement and viewing balance for the user. A hierarchy was created by using shades and contrasts of the same color palette. Certain objects in the application were highlighted with contrasting colors to draws the user's attention (Fig. 3).

\section{Visceral design}

The principles of Wrigley, Popovic and Chamorro-Koc (2008) was adopted in the visceral design. Thus, high-resolution photos of the Pasila campus environment and minimal pop-ups were used. Consequently, the user could be fully immersed in the environment. The pink color in the Haaga-Helia color palette was used to convey a happy and lively feeling and encourage positivity, inviting the user to log in (Fig. 3). After logging in for the first time and creating a profile, the user was directed to a very
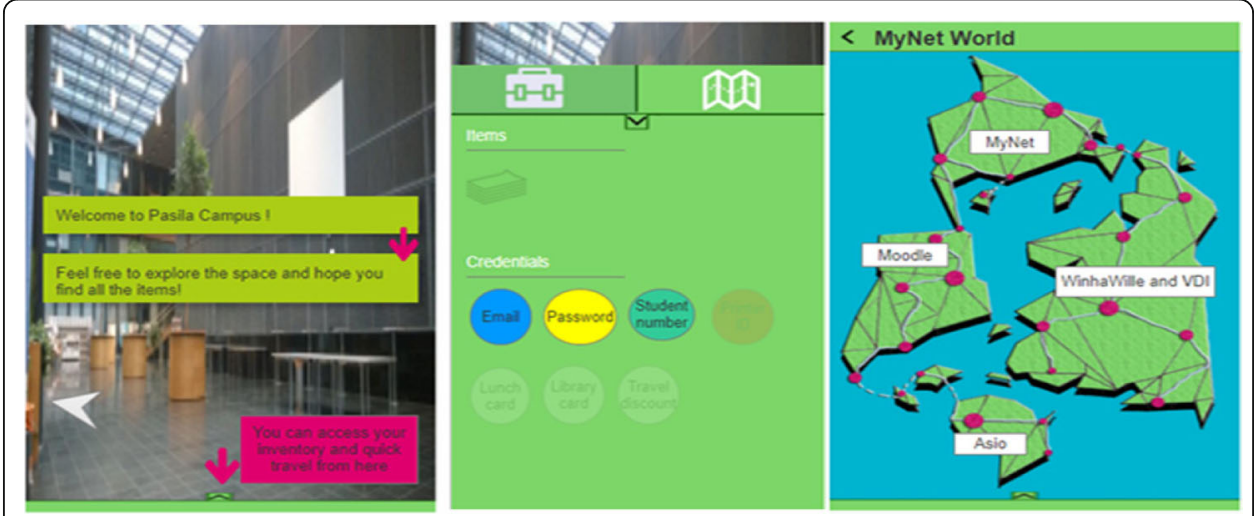

Fig. 3 Screenshots of the application concept 
colorful crossroads page. The images, colors, and events chosen for the application were designed to meet the visceral expectations of the user-that is, the "WOW" factor and immediate response to whether some things were good or bad.

\section{Behavioral design}

In the behavioral design, the principles of Cash, Hartlev and Durazo (2017) were applied. Instead of a normal click and move or scrolling to read content, the design of the application was intended to make the user active. There were events requiring the user to engage and interact with the application for example, starting tour at the premises. To avoid disheartening the user for making mistakes on quizzes or in mini-games, positive feedback was used as well as encouragement to learn more.

\section{Reflective design}

The reflective design was carried out by adopting the research of Hummels and Frens (2009). The gamification of elements created opportunities for deep thinking. Thus, the valuation of the user experience was recalled, and the user could remember the skills and information that they had retrieved during the games.

It is important to note that people learn in different ways (Shaw, 2012). Some learn better with visual stimuli, some through interaction, and some by listening. It was important in the concept to be able to support as many ways of learning as possible. The current information delivery methods in the application include interactive mini-games, videos, and providing abstract information in a concrete manner.

\section{Prototype evaluation}

The usability testing was conducted at the research team's personal lab with recording equipment and a testing script to follow. The testing and evaluation weredone simultaneously for every participant. Twelve participants were divided equally into two different groups (A and B) for the usability testing. According to Nielsen (2012), in a usability testing, 5 users is the most common number for the amount of participants. Nielsen argued that with 5 users, the usability researcher can almost always get close to user testing's maximum benefit-cost ratio. Although with exceptions of quantitative studies, card sorting, and eye tracking testing, the majority of user research should be qualitative, that is aimed at collecting insights to drive the user experience design, not impressive numbers (Nielsen, 2000). Based on Nielsen's research, the research team decided to conducted the test for 6 users to ensure that in the case of cancellation from one user, the participants number is still following the research's guideline. Group A included freshman and sophomore students from Haaga-Helia, who had attended Orientation Week in the past. Group A's participants are only familiar with Haaga-Helia's Orientation Week and therefore, can compare between the current Orientation Week and the conceptual Orientation with an insider's perspective. Group B comprised potential candidates from other polytechnics and universities, who had not experienced Haaga-Helia's Orientation Week. Group B’s participants are outsiders whom have had orientation experience in their own schools, therefore, they can compare between their experience in the past and the orientation experience during the test. The objectives of the usability testing were to provide insightful and valuable information from the 
distinctive groups of users' point of view. Furthermore, the testing was aimed at identifying users' problems with the usability, interface, and content of the application. It was also intended to gather users' feedback and usability rates for the prototype application. The usability rates were important because they would help the team assess how realistic and practical the implementation of the concept was. Errors in the application would be defined according to the users' navigation, control usage, and response to information on the screen. The final purpose was to learn from the users' performance and satisfaction levels and improve the design and functions of the conceptual mock-up to enhance the users' experience. Participants in Group A were asked to read a test scenario, presented in Fig. 4 below.

In the scenario (Fig. 4) four tasks were assigned to complete in the web application. Participants in Group B were asked to read the concept scenario, as they were unfamiliar with the Haaga-Helia system. Then they were given three tasks to complete in the web application.

The evaluation metrics for the usability testing session were for measuring the performance success level that satisfied the usability requirements for the given tasks. Time-to-completion of scenarios and tasks were collected and compared within and between groups. The participants were encouraged to think aloud during their test sessions for recording their thoughts and feelings as feedback. Moreover, the team measured the completion rate for each task without problems made observation notes of each participant's reactions. After the test, the participants were asked to answer a heuristic questionnaire about the application's usability levels on a scale of 1 to 5 as well as to provide open feedback. Tables 4 and 5 displays the results of the participants' evaluations of the conceptual application. The ratings of Groups A and B are presented in Tables 4 and 5 respectively.

The data are color-coded. Green means a positive response and a high rate, yellow represents a mid-point assessment, and red means a negative response and a low rate. In both groups, the average rating was 3.9 out of 5 . The common problems were within the application's "Emergency exit," "Error prevention," "Memory minimized," and "Task orientation" The severity of the problems with "Emergency exit" and "Error prevention" was Level 1, because it prevented users from completing the tasks. "Memory minimized" and "Task orientation" were at Levels 3 and 4, respectively, because they only caused minor frustration, which could be immediately fixed or ignored, and did not prevent users from doing their tasks (Table 4). Group B has a lower average rate than Group A for individual assessment as well as total rate (Table 5). This may be that participants in Group A were Haaga-Helia students, who were already familiar with the facilities on the Pasila campus.

Participants in Group A focused more on the capability of the application's features than the content. Therefore, Group A provided more negative feedback regarding the

Imagine back when you were still a freshman, newly accepted into Haaga-Helia. Instead of requiring you to attend Orientation Week, Haaga-Helia would send your student number and a default password so you could log in to a web application, called Freshman.

Fig. 4 Usability test evaluation scenario 
Table 4 Post-test heuristic evaluation: Group A

\begin{tabular}{|l|l|l|l|l|l|l|l|l|l|}
\hline A & $\begin{array}{l}\text { Feedback } \\
\text { informative }\end{array}$ & $\begin{array}{l}\text { Conventional } \\
\text { language }\end{array}$ & $\begin{array}{l}\text { Emergency } \\
\text { exit }\end{array}$ & $\begin{array}{l}\text { Platform } \\
\text { conventions }\end{array}$ & $\begin{array}{l}\text { Error } \\
\text { prevention }\end{array}$ & $\begin{array}{l}\text { Memory } \\
\text { minimized }\end{array}$ & $\begin{array}{l}\text { UI } \\
\text { learning } \\
\text { process }\end{array}$ & $\begin{array}{l}\text { Information } \\
\text { display }\end{array}$ & $\begin{array}{l}\text { Task } \\
\text { oriented }\end{array}$ \\
\hline U1 & 3 & 4 & 2 & 3 & 2 & 2 & 4 & 4 & 2 \\
\hline U2 & 4 & 4 & 4 & 4 & 4 & 4 & 4 & 4 & 4 \\
\hline U3 & 5 & 5 & 4 & 4 & 5 & 4 & 4 & 4 & 4 \\
\hline U4 & 4 & 5 & 4 & 4 & 4 & 5 & 5 & 5 & 4 \\
\hline U5 & 3 & 5 & 2 & 4 & 5 & 3 & 4 & 3 & 4 \\
\hline U6 & 4 & 5 & 4 & 5 & 5 & 5 & 5 & 5 & 5 \\
\hline Avg & 3.8 & 4.7 & 3.3 & 4.0 & 4.2 & 3.8 & 4.5 & 4.2 & 3.8 \\
\hline 4.0 & & & & & & & & & \\
\hline
\end{tabular}

user flow and navigation within the application (Table 4). Group B, however, gave more positive, open feedback regarding their user experience, the concept design itself, and the VR concept of the Pasila campus (Table 5). However, the participants in Group B were not familiar with the information or content of the application and had trouble learning from the user interface and using the application intuitively. Therefore, they struggled with the navigation as well as the amount of information in their memory load.

Furthermore, both groups rated the application highly on "Feedback informative," "Conventional language," "Platform conventions," "UI learning process," and "Information display". Participants in Group A rated the application by grouping the functions together, and then they determined if the overall tasks were completed (Table 4). This created a polar state between participants whose ratings were all high and those whose ratings were all low. On the contrary, participants in Group B gave the application a neutral assessment, because they had not experienced the Haaga-Helia system previously (Table 5).

In summary, the usability evaluation showed that both first time and experienced users were able to use the application. Moreover, the existing functions were useful and only needed to be improved for performance and user experience enhancement. In addition, the application received positive ratings from Group A and positive open

Table 5 Post-test heuristic evaluation: Group B

\begin{tabular}{|l|l|l|l|l|l|l|l|l|l|}
\hline B & $\begin{array}{l}\text { Feedback } \\
\text { informative }\end{array}$ & $\begin{array}{l}\text { ConventionalEmergency } \\
\text { language }\end{array}$ & exit & & & & & & \\
conventions & Error \\
prevention & $\begin{array}{l}\text { Memory } \\
\text { minimized }\end{array}$ & $\begin{array}{l}\text { UI } \\
\text { learning } \\
\text { process }\end{array}$ & $\begin{array}{l}\text { Information } \\
\text { display }\end{array}$ & $\begin{array}{l}\text { Task } \\
\text { oriented }\end{array}$ \\
\hline U1 & 4 & 4 & 2 & 4 & 4 & 3 & 4 & 5 & 3 \\
\hline U2 & 3 & 5 & 4 & 4 & 4 & 3 & 4 & 4 & 2 \\
\hline U3 & 3 & 3 & 3 & 4 & 3 & 3 & 2 & 4 & 4 \\
\hline U4 & 4 & 4 & 3 & 4 & 3 & 4 & 4 & 4 & 4 \\
\hline U5 & 5 & 5 & 5 & 5 & 5 & 3 & 5 & 5 & 5 \\
\hline U6 & 3 & 4 & 1 & 3 & 1 & 2 & 5 & 4 & 4 \\
\hline Avg & 3.7 & 4.2 & 3.0 & 4.0 & 3.3 & 3.0 & 4.0 & 4.3 & 3.7 \\
\hline 3.7 & & & & & & & & & \\
\hline
\end{tabular}


feedback from Group B. Therefore, the research team continues to work toward resolving the existing problems to complete every aspect of the application.

\section{Discussion}

This study demonstrated the concept of interactive and augmented m-learning for Orientation Week at an institution of higher education. Thus, the findings provide new insights into digital learning methods to enhance students' learning experiences during their first days at university. Past research has emphasized the importance of student engagement in learning and teaching (Vuori, 2014), where technology-enabled learning methods provide solutions to enrich situational learning opportunities. Additionally, the concept presented in this study is instructive regarding the integration of technology-enabled learning methods into other conventional orientation activities, such as tutoring and team building. This is in line with the research on blended learning that highlights the effectiveness of creating more meaningful learning experiences through integrating interactive and augmented m-learning into activities that take place on the campus premises (see, e.g., Garrison \& Kanuka, 2004; Lopez-Perez et al., 2011).

The existing problems in a student's life are considered as their user profile. New students are often young and have never studied at a higher educational institute before, or been away from their home country. Social pressure from home can lead to emotional conflict, such as fear of failure, and moving alone to an unfamiliar place can cause loneliness. Different factors in the environment can lead to anxiety, stress, and pressure, which reduce concentration. Hence, Orientation Week is often not as efficient as it can be. Nonetheless, the Orientation Week does provide a wealth of information to students about the environment and their learning context. It also provides an introduction to the study path, which helps students make decisions about their future career. Nevertheless, not all information is visible during Orientation Week, and the fact that it is mandatory can be stressful for new students. Thus, institutions of higher education should provide an alternative solution to the traditional Orientation Week that provides a fun and relaxing experience to freshmen during their first engagement with university life. If the solution can offer students the safe, open, stimulating environment of the real university premises before they arrive at school, their first impression will be more positive, and they can gain more confidence by getting used to the virtual space.

The user study results suggested that students' studying problems were due to the inflexibility of a fixed Orientation Week. The students' capabilities of using smartphones and experiences of m-learning environments suggested that the orientation learning process could be virtual. Moreover, the evaluation results of the application prototype indicated that the students felt positive and impressed with the concept design and that it would serve their purposes efficiently. Giving students the power to decide when and where they are studying could empower them to continue with their studies. Without the external pressure of mandatory orientation days and with the continuous availability of information, students can move forward at their own pace and customize their learning schedule to suit their preferences.

The technologies to implement in the final product are the AR and VR functionalities of the application regarding the virtual tour of the designated campus and within the Moodle learning environment. Students are able to access the dynamic and interactive study content via their phone camera or their own VR headset. As the number of 
students who own a smartphone, laptop, or tablet grows every year, it is necessary to create an $\mathrm{m}$ - learning environment that is mobile. The most familiar solution for Haaga-Helia students is to upgrade the existing online learning environment to an engaging and interactive solution for their personal mobile devices.

\section{Conclusion}

The research team began with a user study and research into the students' problems regarding the topic of orientation learning at Haaga-Helia. After gathering information by interviewing Haaga-Helia students and analyzing the students' data, the team designed the conceptual solution including a case scenario and low-fi and hi-fi prototypes. Ultimately, the team's goal was to test the conceptual design on test users to evaluate the usability and potential of the initial concept. The usability testing and evaluation process were conducted with 12 participants, divided into Groups A and B. The results show that the conceptual solution is applicable and has the potential for further development in the context of Finland's higher education.

The solution provided by the team is a mobile orientation application for freshmen at universities and polytechnics. More specifically, to exhibit the concept, Haaga-Helia and orientation to the BITe program were chosen. The solution provides a way for new students to gain all the relevant information that a week-long orientation contains at their own pace, through their mobile phone. This solves the problems of missing days of orientation due to illness or late flights, and it reduces the number of man-hours needed on the part of the school to organize the orientation. The remaining challenges to be tackled before the concept can be implemented are to refine the features, the user interface design, as well as the architecture design and implementation. Furthermore, the team will continue to develop the concept design into a completed, functional, hi-fi prototype. The prototype will then be tested and evaluated by students, ensuring that the application is co-created with users and thus meeting users' expectations and requirements.

Discussions with the participants revealed that students would not find the application interesting if it were just an informational website or a list of instructional videos. Therefore, the team wanted to create an application concept using interactive and engaging technologies, such as AR, for the students' own mobile devices. To implement the solution, the team will adopt Unity, as it has good support for creating AR and VR applications. Using Unity will also enable the team to publish on different platforms, such as iOS, Android, and WebGL, as well as create a framework that can be used for further development in Finland's educational field. The team is expected to have a working application to test on BITe students in fall 2018. Based on the feedback given by new students, the application will be developed further and potentially adapted to other degree programs at Haaga-Helia.

The future of a learning environment such as this concept design can be developed to fit the growth of modern technology when VR headsets become more common and affordable for everyone. The learning environment can be completely virtualized with real-time interaction and socialization, similar to the current VR Chat application. Moreover, the AR aspect can be enhanced so that virtual lectures and practical workshops can be shown via HoloLens. The pursuit of higher education is becoming global, where individuals from around the world can attend classes across continents and at 
different universities. The results of this study should also encourage researchers of higher education to empirically explore individuals' attitude and acceptance towards VR and AR technologies by adopting e.g. TAM (Technology acceptance model). The research team hopes that other researchers and students can use its work to continue developing a unified learning environment that makes global education accessible from within one's home.

Funding

The only funding that the authors have received is the cost for proofreading of the article. The funding provided by university that the authors represent.

\section{Availability of data and materials}

The authors of this paper are ready to reproduce the materials and the data including usability test raw data that are presented in the manuscript. The raw data is accessible if and when scientist or reviewer wishing to use or assess it.

\section{Authors' contributions}

NN and TM have conducted the actual study as a project in a Digital Service Project course at Haaga-Helia University of Applied Science. They both equally contributed to this paper. AD act as a course teacher supervised the project progress, prepared the paper template, advise how to write the paper, and reviewed the paper many times. AA, review and commented the paper and provided some background information. All authors read and approved the final manuscript.

\section{Competing interests}

The authors declare that they have no competing interests.

\section{Publisher's Note}

Springer Nature remains neutral with regard to jurisdictional claims in published maps and institutional affiliations.

Received: 14 April 2018 Accepted: 2 July 2018

Published online: 08 October 2018

\section{References}

Abras, C., Maloney-krichmar, D., \& Preece, J. (2004). User-Centered Design. Design, 37(4), 1-14 https://doi.org/10.3233/ WOR-2010-1109.

Acevedo, J. M., \& Yancey, G. B. (2011). Assessing new employee orientation programs. Journal of Workplace Learning, 23(5), 349-354 https://doi.org/10.1108/13665621111141939.

Alamäki, A., \& Mäkinen, K. (2005). Competence development supported by digital means in a knowledge-intensive company. In In E-training practices for professional organizations, (pp. 95-102). Boston: Springer.

Anderson, J. R., Reder, L. M., \& Simon, H. A. (1996). Situated learning and education. Educational Researcher, 25(4), 5-11 https://doi.org/10.3102/0013189X025004005.

Boulos, M. N. K., Wheeler, S., Tavares, C., \& Jones, R. (2011). How smartphones are changing the face of mobile and participatory healthcare: An overview, with example from eCAALYX. Biomedical Engineering Online, 10, 24 https:// doi.org/10.1186/1475-925X-10-24.

Cash, P. J., Hartlev, C. G., \& Durazo, C. B. (2017). Behavioural design: A process for integrating behaviour change and design. Design Studies, 48, 96-128 https://doi.org/10.1016/j.destud.2016.10.001.

Coding, W. I. (2012). Tips \& Tools \# 18: Coding Qualitative Data. ... on Marilyn Waring: New Advances in ..., 16, 1-5.

Dirin, A., \& Nieminen, M. (2015). mLUX:Usability and User experience development framework for m-learning. IJIM, International Journal of Interactive Mobile Technologies. 9(3), 37-51.

Dirin, A., Nieminen, M., \& Kettunen, M. (2013a). Student capabilities to utilize m-learning service in new smart devices. In Proceedings of the 2013 International Conference on Advanced ICT. Sanya, China: Atlantis Press https://doi.org/10. 2991/icaicte.2013.89.

Fitz-Walter, Z., Tjondronegoro, D., \& Wyeth, P. (2011). Orientation Passport: using gamification to engage university students. In Proceedings of the 23rd Australian Computer-Human Interaction Conference on - OzCHI '11, 122-125 https://doi.org/10.1145/2071536.2071554.

Fitz-Walter, Z., Wyeth, P., Tjondronegoro, D., \& Johnson, D. (2014). Exploring the effect of achievements on students attending university orientation. In Proceedings of the first ACM SIGCHI annual symposium on Computer-human interaction in play - CHI PLAY'14, (pp. 87-96) https://doi.org/10.1145/2658537.2658700.

Galitz, W. O. (2007). The Essential Guide to User Interface Design: An Introduction to GUI Design Principles and Techniques (Google eBook). USA: Wiley Publishing, Inc. ISBN-13: 978-0470053423. ISBN-10: 0470053429.

Garrison, D. R., \& Kanuka, H. (2004). Blended learning: Uncovering its transformative potential in higher education. Internet and Higher Education, 7(2), 95-105 https://doi.org/10.1016/j.iheduc.2004.02.001.

Glasersfeld, E. v. (1995). A constructivist approach to teaching. In Constructivism in education, (pp. 3-16).

Gorden, R. (1998). Coding interview responses. Basic Inteviewing Skills, 180-198. Illinois: Waveland Press, Inc. Long Grove. ISBN:978-1-57766-020-0.

Hackos, J. T., \& Redish, J. C. (1998). User and task analysis for Interface design. IEEE Transactions on Professional Communication, 42 https://doi.org/10.1109/TPC.1999.784573. 
Holtzblatt, K., Wendell, J. B., \& Wood, S. (2005). Chapter 8 - building an affinity diagram. In Interactive Technologies, (pp. 159-179) https://doi.org/http://dx.doi.org/10.1016/B978-012354051-5/50009-4.

Hummels, C., \& Frens, J. (2009). The reflective transformative design process. In Proceedings of the 27th international conference extended abstracts on Human factors in computing systems - CHI EA '09, (p. 2655) https://doi.org/10.1145/ 1520340.1520376.

Lopez-Perez, M. V., Perez-Lopez, M. C., \& Rodriguez-Ariza, L. (2011). Blended learning in higher education: Students' perceptions and their relation to outcomes. Computers \& Education, 56(3), 818-826 https://doi.org/10.1016/j. compedu.2010.10.023.

MacDonald, S., \& Headlam, N. (2009). Research Methods Handbook: Introductory guide to research methods for social research. Digital Ed. CLES. (p.35-57) https://cles.org.uk/our-work/publications/research-methodshandbook/

Murphy, C., Hawkes, L., \& Law, J. (2002). How international students can benefit from a web-based college orientation. New Directions for Higher Education, 117(117), 37-44 https://doi.org/10.1002/he.45.

Nielsen, J. (2000). Why You Only Need to Test with 5 Users. Nielsen Norman Group. https://www.nngroup.com/articles/ why-you-only-need-to-test-with-5-users/

Nielsen, J. (2012). How many test users in a usability study. Useit. Com: Jakob Nielsen's Website, 1-5. Retrieved from https://www.nngroup.com/articles/how-many-test-users/

Rosson, M. B., \& Carroll, J. M. (2002). Scenario-Based Design. In The human-computer interaction handbook: fundamentals, evolving technologies and emerging applications, (pp. 1032-1050) https://doi.org/10.1016/j.jbi.2011.07.004.

Seong, D. S. K. (2006). Usability guidelines for designing mobile learning portals. In Proceedings of the 3rd international conference on mobile technology, applications \& systems - mobility '06, 25 https://doi.org/10.1145/1292331.1292359.

Shaw, R. S. (2012). A study of the relationships among learning styles, participation types, and performance in programming language learning supported by online forums. Computers and Education, 58(1), 111-120 https://doi. org/10.1016/j.compedu.2011.08.013.

Suomala, J., Alajääski, J., \& Alamäki, A. (1999). The Characteristics of High Quality Programming and High Quality Software in Students' Lego/Logo Programming. In Proceedings of the Seventh European Logo Conference: Eurologo'99, (pp. 344-349) a 20th Century Epilog.

Todorovic, D. (2008). Gestalt principles. Scholarpedia, 3(12), 5345 https://doi.org/10.4249/scholarpedia.5345.

Usability Research Group. (2002). User Centred Design Methods. Indiana University. http://www.indiana.edu/ usable/ presentations/ucd_methods.pdf. Accessed 1 Feb 2016.

Vuori, J. (2014). Student engagement: buzzword of fuzzword? Journal of Higher Education Policy and Management, 36(5), 509-519 https://doi.org/10.1080/1360080X.2014.936094.

Wrigley, C., Popovic, V., \& Chamorro-Koc, M. (2008). Visceral hedonic rhetoric: Emerging research in design and emotion. In Proceedings from the 6th Conference on Design and Emotion 2008.

\section{Submit your manuscript to a SpringerOpen ${ }^{\circ}$ journal and benefit from:}

- Convenient online submission

- Rigorous peer review

- Open access: articles freely available online

- High visibility within the field

- Retaining the copyright to your article 